\title{
Effects of Sodium Poly(styrene sulfonate) on Antibody Production and Cell Growth of HB4C5 Hybridoma Cells
}

\author{
Kazuhiko Nagira, Midori Hayashida,* Masanobu Shiga, \\ Kazumi Sasamoto, Ken'yu Kina, Kazuhiro Osada, ${ }^{*}$ \\ Takuya Sugahara, ${ }^{*}$ Takashi Hara, ${ }^{*}$ Yasuji Yamamoto, ${ }^{*}$ \\ and Hiroki MURAKAMI* \\ Dojindo Laboratories, Tabaru 2025-5, Mashiki-machi, \\ Kumamoto 861-22, Japan \\ * Laboratory of Cellular Regulation Technology, Graduate \\ School of Genetic Resources Technology, Kyushu University, \\ 6-10-1, Hakozaki, Higashi-ku, Fukuoka 812, Japan
}

(Received January 13, 1995)

\begin{abstract}
The effects of sodium poly(styrene sulfonate) on an antibody production and cell growth of a hybridoma cell were studied. Although sodium poly(styrene sulfonate) inhibited the antibody production and cell growth at lower concentration with increasing molecular weight in serum-free cultures, sodium poly(styrene sulfonate)s with medium weight-average molecular weights $\left(M_{w}\right)$ such as 35000 and 18000 suppressed antibody production without inhibiting cell growth at appropriate concentrations. Sodium poly(styrene sulfonate) $\left(M_{w}=35000\right)$ decreased the extracellular concentration of a $\mu$ heavy chain forming an antibody, while it had no effect on an intracellular antibody or $\mu$ heavy chain concentration. This suggests that the sodium poly(styrene sulfonate) suppresses secreting the antibody assembled by $\mu$ heavy chains and $\lambda$ light chains out of the cell without inhibiting the synthesis and association of both chains in the cell.

KEY WORDS Sodium Poly(styrene sulfonate) / Antibody Production / Cell Growth / Cytotoxicity / Immunosuppression /
\end{abstract}

To clarify effects of polymers on antibody production, one of their miscellaneous biological activities, we examined various polymers in a serum-free culture of human-human hybridomas producing monoclonal antibodies. It is valuable to elucidate their effects on antibody production when producing monoclonal antibodies by hybridomas, developing medicines such as immunostimulants and immunosuppressants, and improving biocompatible materials. We recently reported that cationic polymers such as polylysine ${ }^{1}$ and chitosan ${ }^{2}$ enhance antibody production and anionic polysaccharides ${ }^{2}$ such as dextran sulfate and xylan suppress it. In addition, several anionic polymers were synthesized and examined for cytotoxicity, antiviral activity, antitumor activity, and immunomodulating activity in vivo and in vitro, and some maleic acid copolymers have been found effective immunomodulators. ${ }^{3-8}$ However, polystyrenesulfonates have been rarely studied for biological activity, and have been only examined for cytotoxicity at high concentrations. ${ }^{9-11}$

This report discusses the effects of sodium poly(styrene sulfonate) (PSS) on antibody production and cell growth of human-human hybridoma cells.

\section{EXPERIMENTAL}

\section{Materials}

PSSs with narrow dispersed molecular weight were purchased from Polyscience Inc. 
Table I. Weight-average molecular weight, $M_{w}$ and molecular weight distribution, $M_{w} / M_{n}$ of sodium poly(styrene sulfonate)s

\begin{tabular}{cc}
\hline$M_{w}{ }^{\mathrm{a}}$ & $M_{w} / M_{n}{ }^{\mathrm{a}}$ \\
\hline 1800 & 1.25 \\
5400 & 1.10 \\
8000 & 1.10 \\
18000 & 1.10 \\
35000 & 1.10 \\
$78000^{\mathrm{b}}$ & $2.70^{\mathrm{b}}$ \\
100000 & 1.10
\end{tabular}

${ }^{a}$ These values were determined by LALLS and GPC at Polysience Inc. (PA, U.S.A.). ${ }^{\mathrm{b}}$ These values were determined at $40^{\circ} \mathrm{C}$ on a Shimadzu LC-6A GPC system, which consisted of a Tosoh TSK G3000SW $\mathrm{XL}_{\mathrm{XL}}$ column and Shimadzu RID-6A differential refractometer, using a calibration curve made from other sodium poly(sytrene sulfonate)s in the table. The eluent was $0.2 \mathrm{M}$ aqueous sodium salfate containing $10 \%$ methanol, and the flow rate was $0.6 \mathrm{ml} \mathrm{min}^{-1}$.

(PA, U.S.A.). A poly(styrene sulfonic) acid $\left(M_{w}=70000\right)$ with a broad dispersed molecular weight was also purchased from Polyscience Inc. (PA, U.S.A.), and was neutralized by aqueous sodium hydroxide before use. The weight-average molecular weights and molecular weight distribution $\left(M_{w} / M_{n}\right)$ of PSSs are summarized in Table I. Other chemicals were purchased from Wako Pure Chemicals (Osaka, Japan).

Anti-human antibodies and a peroxidaseconjugated anti-human antibody were purchased from TAGO (CA, U.S.A.). The ERDF culture medium was purchased from Kyokuto Pharmaceutical Industrial Co. (Tokyo, Japan). Human transferrin was from Sigma Chemical Co. (St. Louis, MO, U.S.A.), insulin from Novo Nordisk (Denmark), and calf bovine serum (CBS) from Cell Culture Laboratories (OH, U.S.A.). Block Ace, a blocking agent, was purchased from Dainippon Pharmaceuticals (Japan), and a silver-stain kit from Bio-Rad (CA, U.S.A.).

\section{Instruments}

Cell numbers were determined with a
CC-130A Microcellcounter (Toa Medical Electronics Co., Tokyo, Japan). IgM and $\mu$ heavy chain concentrations were determined by an enzyme-linked immunosorbent assay (ELISA) with an EAR-400 plate reader (SLT Labinstruments, Austria). Intensity of color development after western blotting was measured with a personal densitometer (Molecular Dynamics, CA, U.S.A.).

\section{Cell and Cell Maintenance}

Human-human hybridoma HB4C5 cells that produce monoclonal $\operatorname{IgM}$ are a fusion product between NAT-30 cell selected from Namalwa cell and lymphocytes from lymph nodes of lung cancer patients. ${ }^{12}$ These hybridoma cells were maintained in ERDF medium containing ITES (insulin, $5 \mu \mathrm{g} \mathrm{ml}^{-1}$; transferrin, $20 \mu \mathrm{g} \mathrm{ml}^{-1}$; ethanolamine, $20 \mu \mathrm{M}$; sodium selenite, $25 \mathrm{nM})^{13}$ at $37^{\circ} \mathrm{C}$ under humidified $5 \% \mathrm{CO}_{2} / 95 \%$ air.

\section{Cell Culture}

HB4C5 hybridoma cells were inoculated into $2 \mathrm{ml}$ plastic dishes (Falcon) at a density of $1 \times 10^{5}$ cells $\mathrm{ml}^{-1}$ and cultured in ITES-ERDF medium containing various concentrations of PSSs at $37^{\circ} \mathrm{C}$ under humidified $5 \% \mathrm{CO}_{2} / 95 \%$ air for 4 or 8 days. The hybridoma cells were also cultivated in ERDF medium containing $5 \%$ CBS with $50 \mu \mathrm{g} \mathrm{ml}^{-1}$ of PSS $\left(M_{w}=18000\right)$ or $5 \mu \mathrm{g} \mathrm{ml}^{-1}$ of PSS $\left(M_{w}=100000\right)$ under similar conditions. The hybridoma cells were cultured in the absence of PSS under similar conditions as the control. Each cell culture was duplicated.

\section{Determination of Total and Viable Cell Numbers}

Total cell numbers were determined with a microcellcounter and viable cell numbers were measured by the trypan blue dye exclusion test.

\section{Determination of IgM Concentration}

$\mu$ Heavy chain concentrations in supernatants of the cultured fluids were measured as IgM concentrations by ELISA, using an 
anti-human $\mu$ heavy chain antibody (4302, TAGO) as the first antibody, and peroxidaseconjugated anti-human $\mu$ heavy chain antibody (4502, TAGO) as the second antibody, ${ }^{14}$ because the $\mu$ heavy chains forming IgM are only secreted from hybridoma cells (unpublished data). Intracellular $\mu$ heavy chain concentrations were determined in the same manner as above, and intracellular IgM concentrations were also measured by ELISA using an anti-human $\lambda$ light chain antibody (4308, TAGO) as the first antibody, and peroxidase-conjugated anti-human $\mu$ heavy chain antibody (4502, TAGO) as the second antibody.

\section{Determination of Intracellular and Extracellular IgM Concentration}

HB4C5 hybridoma cells were inoculated into $2 \mathrm{ml}$ plastic dishes (Falcon) at a density of $1.3 \times 10^{6}$ cells ml ${ }^{-1}$ and cultured in ITESERDF medium containing $5 \mu \mathrm{g} \mathrm{ml}^{-1}$ PSS $\left(M_{w}=35000\right)$ at $37^{\circ} \mathrm{C}$ under humidified $5 \%$ $\mathrm{CO}_{2} / 95 \%$ air for 12 hours. Hybridoma cells were also cultured in the absence of PSS under similar conditions as the control. Each cell culture was duplicated. Extracellular IgM concentrations in the supernatants were measured every 2 hours. The centrifuged hybridoma cells were washed with phosphatebuffered saline (PBS, pH 7.4), collected by centrifugation again, and suspended in PBS. The suspended cells were crushed by ultlasonication in an ice-cold water bath. The IgM and the $\mu$ heavy chain concentrations in the ultrasonicated cell fluids were measured as intracellular concentrations every 2 hours.

\section{Gel Electrophoresis and Western Blotting}

HB4C5 hybridoma cells were inoculated into $10 \mathrm{ml}$ plastic dishes (Falcon) at a density of $1 \times 10^{5}$ cells $\mathrm{ml}^{-1}$ and cultured in ITES-ERDF medium containing $5 \mu \mathrm{g} \mathrm{ml}^{-1}$ PSS $\left(M_{w}=\right.$ 35000 ) at $37^{\circ} \mathrm{C}$ under humidified $5 \% \mathrm{CO}_{2} / 95 \%$ air for 4 days. The hybridoma cells were also cultured in the absence of PSS under similar conditions as the control. Supernatants of the cultured fluids were dialyzed to eliminate low molecular-weight materials, and concentrated by freeze-drying. The concentrates were diluted with PBS before the diluted solutions were reacted with 2-mercaptoethanol in $50 \mathrm{mM}$ Tris- $\mathrm{HCl}$ buffer solution ( $\mathrm{pH}$ 6.8) containing $1.5 \% \mathrm{SDS}$ at $100^{\circ} \mathrm{C}$ for 5 minutes. The reaction mixtures were electrophoresed on $10 \%$ SDSPAGE gels in $25 \mathrm{mM}$ Tris- $193 \mathrm{mM}$ glycine buffer solution ( $\mathrm{pH} 8.3$ ) with $0.1 \%$ SDS,${ }^{15}$ then stained by a silver-stain kit or subjected to Western blotting. The electrophoresed materials on the SDS-PAGE gel were electrotransferred on to a nitrocellulose membrane in $25 \mathrm{mM}$ Tris- $193 \mathrm{mM}$ glycine buffer solution (pH 8.3) with $20 \%$ methanol. ${ }^{16}$ Each blotted membrane was blocked with the Block Ace overnight at $4^{\circ} \mathrm{C}$. After washing with PBS containing $0.05 \%$ Tween 20 , the blocked membrane was incubated with peroxidaseconjugated anti-human $\mu$ heavy and $\lambda$ light antibodies at $37^{\circ} \mathrm{C}$ for 2 hours. The color reaction was developed with $1.6 \mathrm{mM}$ 4-chloro1-naphthol and $0.01 \% \mathrm{H}_{2} \mathrm{O}_{2}$ in PBS with $20 \%$ methanol. ${ }^{17}$ The intensity of color development was measured with the densitometer.

\section{RESULTS}

\section{Effects of Molecular Weight on Cell Growth}

As shown in Figure 1, cell growth was inhibited depending on the molecular weight of PSS. PSSs with low $M_{w}$ such as 1800,5400 , and 8000 did not inhibit cell growth, nor disrupt the cell membranes at any tested concentration as judged by light microscopy. However, PSSs with $M_{w}$ of more than 18000 inhibited cell growth at several concentrations. For example, approximately $80 \%$ of cell growth of the control was observed with $500 \mu \mathrm{g} \mathrm{ml}^{-1}$ of PSS $\left(M_{w}=18000\right), 50 \mu \mathrm{g} \mathrm{ml}^{-1}$ of PSS $\left(M_{w}=35000\right), 5 \mu \mathrm{g} \mathrm{ml}^{-1}$ of PSS $\left(M_{w}=78000\right)$ that was prepared from neutralized polystyrenesulfonic acid $\left(M_{w}=70000\right)$, or $5 \mu \mathrm{g} \mathrm{ml}^{-1}$ of PSS $\left(M_{w}=100000\right)$. PSS 


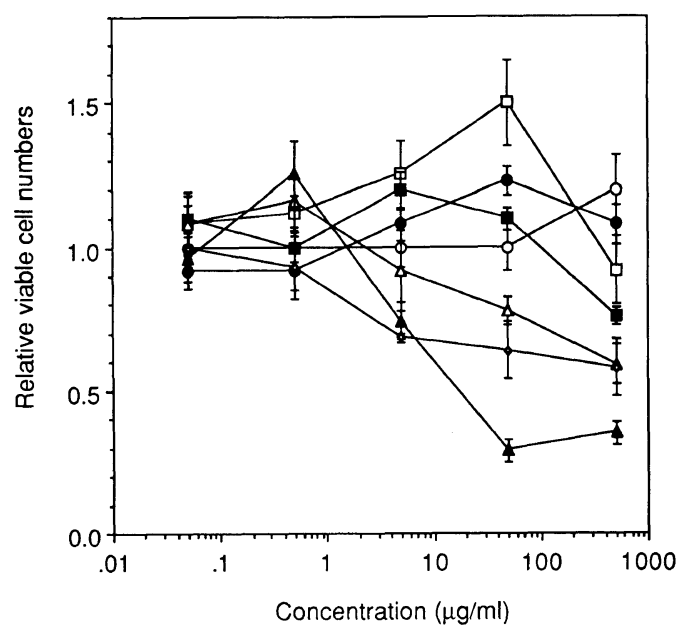

Figure 1. Effects of molecular-weight of sodium poly(styrene sulfonate) on cell growth of HB4C5 hybridoma. Hybridoma cells were cultured in ITES-ERDF medium containing from $0.05 \mu \mathrm{g} \mathrm{ml}^{-1}$ to $500 \mu \mathrm{g} \mathrm{ml}^{-1}$ of sodium poly(styrene sulfonate) for 4 days. Each relative viable cell number is based on the ratio of viable cell number in the presence of sodium poly(styrene sulfonate) against that in the control, and is expressed as the mean with the standard deviation of four measurements in duplicated cultures. $\bigcirc$, $M_{w}=1800 ; \bigcirc, M_{w}=5400 ; \square, M_{w}=8000 ; \square, M_{w}=18000$; $\triangle, M_{w}=35000 ; \Delta, M_{w}=78000 ; \diamond, M_{w}=100000$.

$\left(M_{w}=78000\right)$ with a broad dispersed molecular weight inhibited most cell growth, and gave about $30 \%$ of the cell growth of the control above $50 \mu \mathrm{g} \mathrm{ml}^{-1}$. PSSs with narrow dispersed molecular weight inhibited most cell growth with increasing $M_{w}$. Seventy-six $\%, 59 \%$, and $58 \%$ of the cell growth of the control were given by $500 \mu \mathrm{g} \mathrm{ml}^{-1}$ of PSS $\left(M_{w}=18000\right)$, PSS $\left(M_{w}=35000\right)$ and PSS $\left(M_{w}=100000\right)$, respectively. Cell disruption and shrinkage were observed, as judged by light microscopy with above $500 \mu \mathrm{g} \mathrm{ml}^{-1}$ of PSS $\left(M_{w}=18000\right)$, and above $50 \mu \mathrm{g} \mathrm{ml}^{-1}$ of PSS $\left(M_{w}=35000\right)$, PSS $\left(M_{w}=78000\right)$, and PSS $\left(M_{w}=100000\right)$.

\section{Effects of Molecular Weight on IgM Production}

Figure 2 shows IgM production in the cultured fluid when adding PSSs with various molecular weights. IgM production was not suppressed below $50 \mu \mathrm{g} \mathrm{ml}^{-1}$ of PSS $\left(M_{w}=\right.$ 1800 ), while $500 \mu \mathrm{g} \mathrm{ml}^{-1}$ of this PSS gave $80 \%$

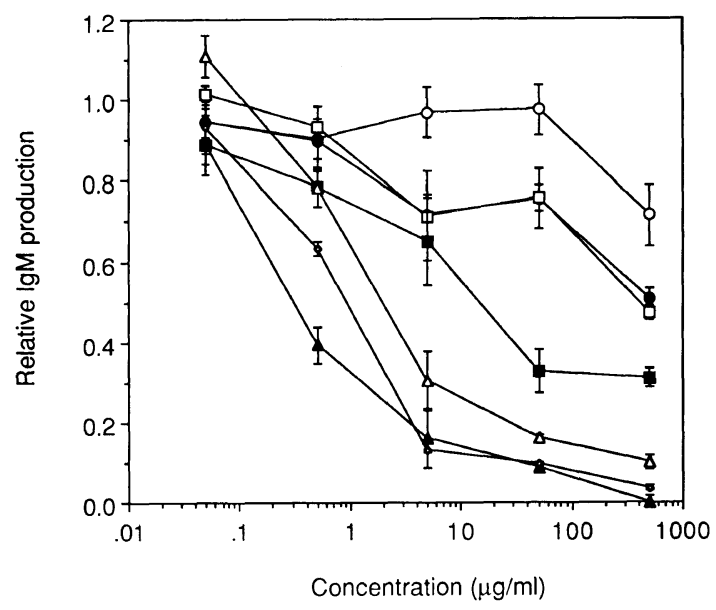

Figure 2. Effects of molecular-weight of sodium poly(styrene sulfonate) on IgM production of HB4C5 hybridoma. Hybridoma cells were cultured in ITES-ERDF medium containing from $0.05 \mu \mathrm{g} \mathrm{ml}^{-1}$ to $500 \mu \mathrm{g} \mathrm{ml}^{-1}$ of sodium poly(styrene sulfonate) for 4 days. Each relative IgM production is based on the ratio of IgM production in the presence of sodium poly(styrene sulfonate) against that in the control, and is expressed as the mean with the standard deviation of four measurements in duplicated cultures. $\bigcirc, M_{w}=1800 ; \bigcirc, M_{w}=5400 ; \square, M_{w}=8000 ; \square$, $M_{w}=18000 ; \triangle, M_{w}=35000 ; \Delta, M_{w}=78000 ; \diamond, M_{w}=$ 100000 .

of the IgM production of the control. Five hundreds $\mu \mathrm{g} \mathrm{ml}^{-1}, 50 \mu \mathrm{g} \mathrm{ml}^{-1}$, and $5 \mu \mathrm{g} \mathrm{ml}^{-1}$ of PSS $\left(M_{w}=5400\right.$ or 8000$)$ gave approximately $50 \%, 70 \%$, and $70 \%$ of the IgM production of the control, respectively. Nearly $30 \%$ of the IgM production of the control was given at above $50 \mu \mathrm{g} \mathrm{ml}^{-1}$ of PSS $\left(M_{w}=18000\right)$. Five hundreds $\mu \mathrm{g} \mathrm{ml}^{-1}, 50 \mu \mathrm{g} \mathrm{ml}^{-1}$, and $5 \mu \mathrm{g} \mathrm{ml}^{-1}$ of PSS $\left(M_{w}=35000\right)$ gave approximately $10 \%$, $20 \%$, and $30 \%$ of the $\operatorname{IgM}$ production of the control, respectively. PSS $\left(M_{w}=78000\right.$ or 100000) of the same concentrations as described above gave nearly $5 \%, 10 \%$, and $20 \%$ of the IgM production of the control, respectively. Thus, PSSs suppressed more IgM production at lower concentrations with increasing molecular weight. PSSs themselves had no effect on ELISA assay at any concentration. 
Time Course of Cell Growth and IgM Production

As shown in Figure 3, the time course of cell growth in the presence of $5 \mu \mathrm{g} \mathrm{ml}^{-1}$ of PSS $\left(M_{w}=35000\right)$ was the same as that of the control for 8 days. Figure 4 shows the time course of IgM production within 8 days in presence of $5 \mu \mathrm{g} \mathrm{ml}^{-1}$ of PSS $\left(M_{w}=35000\right)$.

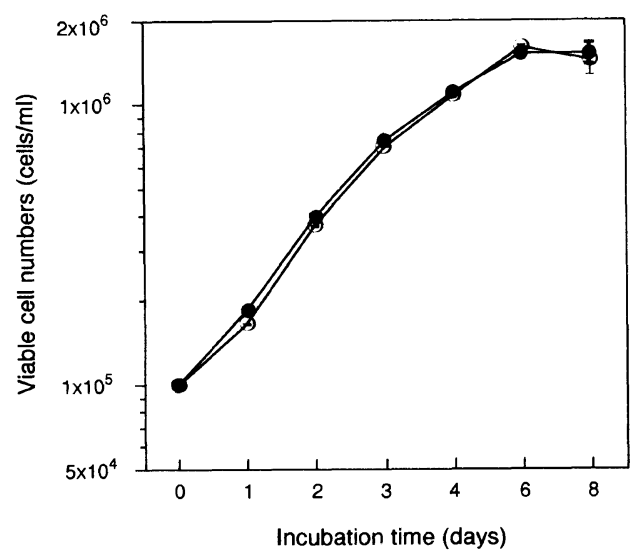

Figure 3. Time course of cell growth of HB4C5 hybridoma. Each viable cell number is expressed as the mean with the standard deviation of four measurements in duplicated cultures. $5 \mu \mathrm{g} \mathrm{ml}^{-1}$ of sodium poly(styrene sulfonate) $\left(M_{w}=35000\right)$; $\bigcirc$, non.

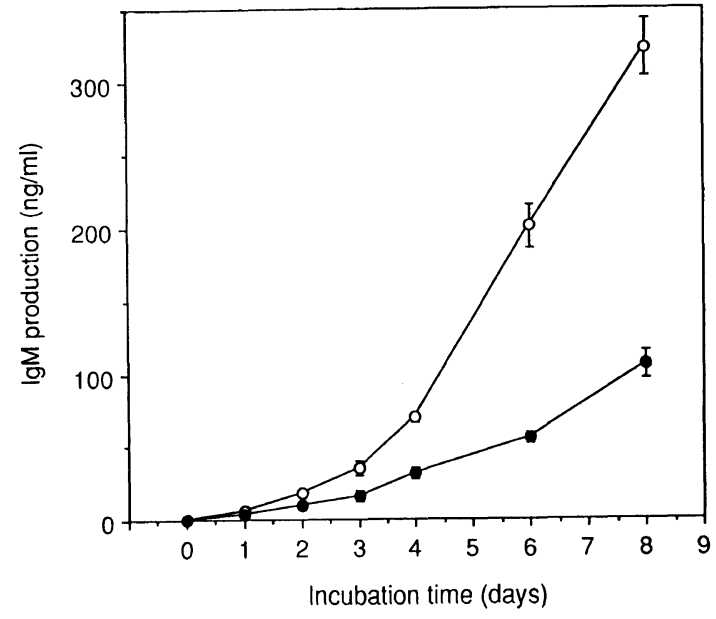

Figure 4. Time course of IgM production of HB4C5 hybridoma. Each IgM production is expressed as the mean with the standard deviation of four measurements in duplicated cultures., $5 \mu \mathrm{g} \mathrm{ml}^{-1}$ of sodium poly(styrene sulfonate) $\left(M_{w}=35000\right)$; $\bigcirc$, non.
PSS began to suppress IgM production at the second or third day, and gave approximately $30 \%$ of the $\operatorname{IgM}$ production of the control at the eighth day. PSS also decreased IgM productivity, because IgM production per day was $63 \mathrm{ng} \mathrm{ml}^{-1} \cdot \mathrm{day}^{-1}$ in the control and $18 \mathrm{ng} \mathrm{ml}^{-1} \cdot \mathrm{day}^{-1}$ in the presence of PSS in the second half of cultivation when cell growth was confluent.

\section{Effect on $\mu$ Heavy and $\lambda$ Light Chains Secreted in Cultured Fluid}

To clarify the effects of PSS $\left(M_{w}=35000\right)$ on the compositions of $\mu$ heavy and $\lambda$ light chains in the cultured fluid, reduced $\operatorname{IgM}$ in the $\mu$ heavy and $\lambda$ light chains with 2-mercaptoethanol was assayed by electrophoresis on SDS-PAGE gels. As shown in Figure 5, $5 \mu \mathrm{g} \mathrm{ml}^{-1}$ of the PSS significantly decreased $\mu$ heavy chain concentration. Table II shows each intensity of color development of the $\mu$ heavy and $\lambda$ light chains by measuring with the densitometer after electrophoresis on SDSPAGE followed by western blotting. The intensity of $\mu$ heavy chain was 2.19 in the presence of the PSS and 9.09 in the control, thus showing that PSS suppressed the secretion of $\mu$ heavy chain to $25 \%$ of the control. The

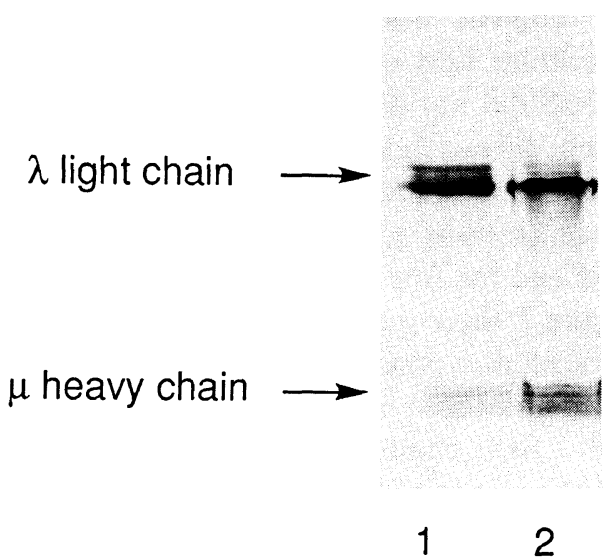

Figure 5. SDS-PAGE analysis of IgM obtained form HB4C5 hybridoma cells. $\lambda$ Light and $\mu$ heavy chains were detected by silver staining. Lane $1,5 \mu \mathrm{g} \mathrm{ml}^{-1}$ of sodium poly(styrene sulfonate) $\left(M_{w}=35000\right)$; Lane 2 , non. 
Table II. Western blot analysis of $\mu$ and $\lambda$ chains produced by $\mathrm{HB} 4 \mathrm{C} 5$ cells in the presence of sodium poly(styrene sulfonate) ${ }^{\mathrm{a}}$

\begin{tabular}{lccc}
\hline & \multicolumn{3}{c}{ Intensity of color development } \\
\cline { 2 - 4 } & $\mu$ chain & $\lambda$ chain & $\lambda$ chain $-\mu$ chain \\
\hline Non & $9.09 \pm 0.45$ & $18.38 \pm 0.90$ & $9.29 \pm 0.46$ \\
PSS & $2.19 \pm 0.13$ & $11.77 \pm 0.50$ & $9.58 \pm 0.57$
\end{tabular}

${ }^{a}$ Hybridoma cells were cultured in ITES-ERDF medium containing $5 \mu \mathrm{g} \mathrm{ml}^{-1}$ sodium poly(styrene sulfonate) $\left(M_{w}=35000\right)$ for 4 days. Each intensity of color development was measured with the densitometer after western blotting, and is expressed as the mean with the standard deviation of four measurements in duplicated cultures.

difference between the intensity of $\mu$ heavy chain and that of $\lambda$ light chain was 9.58 in the presence of the PSS and 9.29 in the control, thus indicating that PSS had no effect on the independent secretion of $\lambda$ light chain.

\section{Effects on Intracellular and Extracellular IgM Concentrations}

Figure 6 shows the intracellular and extracellular IgM concentrations per viable cell within 12 hours after inoculation in presence of $5 \mu \mathrm{g} \mathrm{ml}^{-1}$ of PSS $\left(M_{w}=35000\right)$. PSS slightly decreased extracellular IgM concentration after 4 hours, and lowered it to nearly $45 \%$ of the control after 12 hours. However, intracellular IgM concentration in the presence of PSS did not differ from that of the control much. Intracellular $\mu$ heavy chain concentration was measured to clarify the intracellular concentrations of $\mu$ heavy chain assembling $\operatorname{IgM}$ and the free $\mu$ heavy chains. As shown in Figure 7, there were no differences between the intracellular concentrations of the $\mu$ heavy chain and those of $\operatorname{IgM}$ assembled by $\mu$ heavy and $\lambda$ light chains. The intracellular $\mu$ heavy chain concentration in the presence of the PSS was similar to that of the control.

\section{Effects of CBS on Suppressing the IgM Pro- duction by PSS}

Table III shows cell growth and IgM pro-

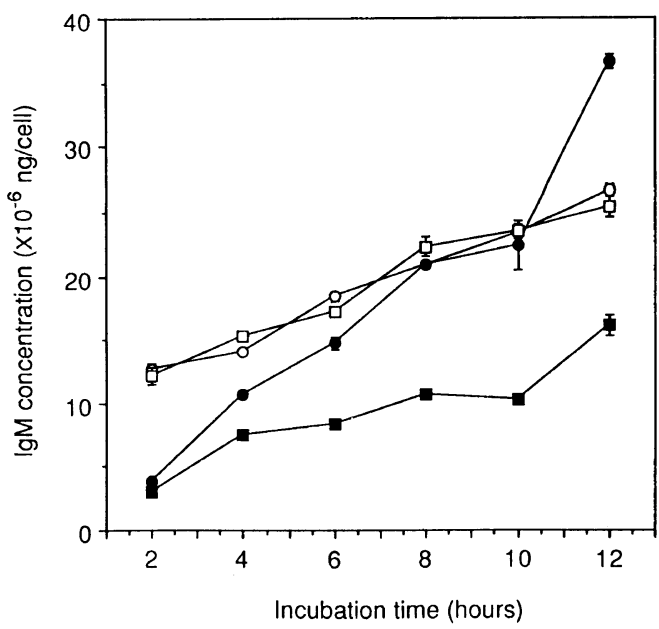

Figure 6. Time course of extracellular and intracellular IgM concentrations. Each extracellular and intracellular IgM concentration per viable cell are expressed as means with the standard deviation of four measurements in duplicated cultures. $\square$, extracellular concentration, $5 \mu \mathrm{g} \mathrm{ml}^{-1}$ sodium poly(styrene sulfonate) $\left(M_{w}=35000\right)$; $\square$, intracellular concentration, $5 \mu \mathrm{g} \mathrm{ml}^{-1}$ sodium poly(styrene sulfonate) $\left(M_{w}=35000\right)$;, extracellular concentration, non; $\bigcirc$, intracellular concentration, non.

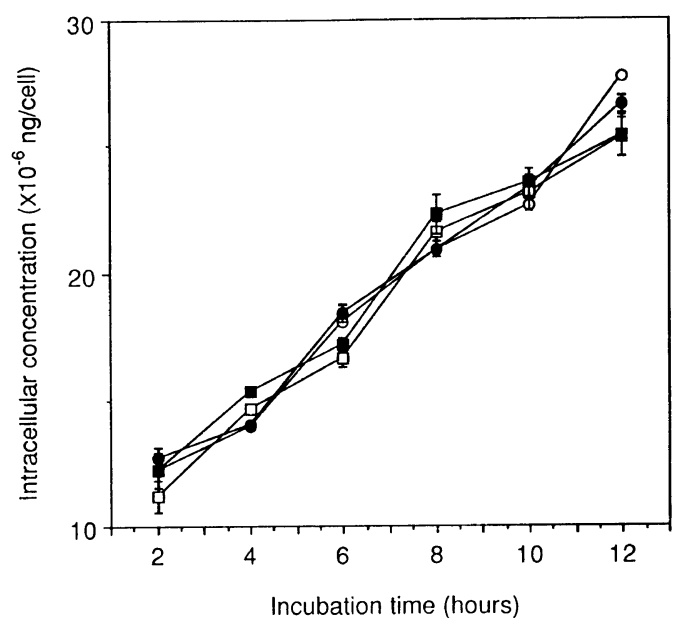

Figure 7. Time course of intracellular $\operatorname{IgM}$ and $\mu$ heavy chain concentrations. Each intracellular IgM and $\mu$ heavy chain concentration per viable cell are expressed as means with the standard deviation of four measurements in duplicated cultures. $\square$, IgM concentration, $5 \mu \mathrm{g} \mathrm{ml}^{-1}$ sodium poly(styrene sulfonate) $\left(M_{w}=35000\right) ; \square, \mu$ heavy chain concentration, $5 \mu \mathrm{g} \mathrm{ml}^{-1}$ sodium poly(styrene sulfonate) $\left(M_{w}=35000\right)$;, IgM concentration, non; $\bigcirc, \mu$ heavy chain concentration, non. 
Table III. Effects of CBS on suppressing IgM production by sodium polystyrenesulfonate ${ }^{a}$

\begin{tabular}{|c|c|c|c|}
\hline \multirow{2}{*}{\multicolumn{2}{|c|}{ Type of medium }} & $\begin{array}{l}\text { Total cell } \\
\text { numbers }\end{array}$ & $\begin{array}{c}\operatorname{IgM} \\
\text { production }\end{array}$ \\
\hline & & $\times 10^{6}$ cells ml $\mathrm{ml}^{-1}$ & $\mathrm{ng} \mathrm{ml}{ }^{-1}$ \\
\hline \multicolumn{4}{|c|}{ (A) With serum (5\%CBS) } \\
\hline & Non & $2.92 \pm 0.04$ & $274 \pm 8$ \\
\hline & $\operatorname{PSS}\left(M_{w}=18000\right)$ & $2.67 \pm 0.09$ & $250 \pm 9$ \\
\hline & PSS $\left(M_{w}=100000\right)$ & $2.68 \pm 0.03$ & $270 \pm 6$ \\
\hline \multicolumn{4}{|c|}{ (B) Serum-free (ITES) } \\
\hline & Non & $1.14 \pm 0.02$ & $101 \pm 5$ \\
\hline & PSS $\left(M_{w}=18000\right)$ & $1.24 \pm 0.04$ & $33 \pm 5$ \\
\hline & PSS $\left(M_{w}=100000\right)$ & $0.77 \pm 0.01$ & $12 \pm 2$ \\
\hline
\end{tabular}

${ }^{a}$ Hybridoma cells were cultured in serum-containing or serum-free medium in the presence of $50 \mu \mathrm{g} \mathrm{ml}^{-1}$ sodium poly(styrene sulfonate) $\left(M_{w}=18000\right)$ or $5 \mu \mathrm{g} \mathrm{ml} \mathrm{so-}$ dium poly(styrene sulfonate) $\left(M_{w}=100000\right)$ for 4 days. Each total cell number and IgM production are expressed as means with the standard deviation of four measurements in duplicated cultures.

duction in 5\% CBS-ERDF medium and ITESERDF medium in the presence of PSSs $\left(M_{w}=\right.$ 18000 and 100000). IgM production was suppressed, and cell growth was not inhibited in ITES-ERDF medium containing $50 \mu \mathrm{g} \mathrm{ml}^{-1}$ of PSS $\left(M_{w}=18000\right)$. However, both cell growth and IgM production in 5\% CBS-ERDF medium with $50 \mu \mathrm{g} \mathrm{ml}^{-1}$ PSS were similar to those of the control. The same results obtained when using $5 \mu \mathrm{g} \mathrm{ml}^{-1}$ of PSS $\left(M_{w}=100000\right)$.

\section{DISCUSSION}

As shown Figures 1 and 2, PSSs with medium $M_{w}$ such as 35000 and 18000 suppressed IgM production without inhibiting cell growth at low concentrations. Other anionic polymers such as polyacrylic acid, polyvinylsulfonic acid and potassium polyvinyl sulfate decreased IgM production and inhibited cell growth above $500 \mu \mathrm{g} \mathrm{ml}^{-1}$. However, they had no effect on IgM production at concentrations where they did not inhibit cell growth (data not shown). Although several anionic polysaccharides such as dextran sulfate, xylan and $\lambda$-carrageenan suppressed the IgM production without inhibiting the cell growth, their suppression was weak, and IgM production was suppressed to only $50 \%$ of the control at $1000 \mu \mathrm{g} \mathrm{ml}^{-1} .^{2}$ The reason for the high suppressing activity of PSS seems to be that the affinity of PSS for cell membranes is enhanced by a hydrophobic group such as the benzene ring as compared with other anionic polymers. PSS interacts with cell membranes more strongly than other anionic polymers such as polyacrylate, dextran sulfate and polyvinyl sulfate, as shown by intracellular calcium levels. ${ }^{10}$ alt-2-Cyclohexyl1,3-dioxepin-5-ene/maleic acid copolymers modified by grafting hydrophobic groups enhance the release of superoxide from dimethyl sulfoxide (DMSO)-differentiated HL60 cells $^{8}$ and alt-3,4-dihydroxyphenylprop-1ene/maleic acid copolymers with hydrophobic groups interact largely with rat small intestinal epithelial cells. ${ }^{7}$ Several cationic polymers such as polyethyleneimine and polyallylamine inhibit cell growth only at $1 \mu \mathrm{g} \mathrm{ml}^{-1}$ (data not shown), whereas chitosan enhances IgM production without inhibiting cell growth ${ }^{2}$ and polylysine increases the IgM production but slightly inhibits cell growth at $1 \mu \mathrm{g} \mathrm{ml}^{-1} .^{1}$ This suggests that cationic polymers interact more easily with cell membranes mainly composed of anionic phospholipids than cationic polymers, and that hydrophilic and rigid main chains in chitosan and polylysine weaken interactions with cell membranes and make favorable situations to secret IgM out of cells. Polystyrenesulfonic acid is intercalated into human epithelial cell membranes and polylysine binds to cell surfaces. ${ }^{11}$ These different interactions with cells might cause opposite actions for the IgM production.

PSS suppressed IgM production and inhibited cell growth depending on both its $M_{w}$ and concentrations (see Figures 1 and 2). The molecular weights of ionic polymers influence cell growth, antibody production and other biological responses. Polymeric chitosans enhance antibody production without inhibiting 
cell growth, while oligomeric chitosans have no effect on antibody production. ${ }^{2}$ A polylysine has been shown to inhibit cell growth ${ }^{18}$ and enhance antibody production ${ }^{1}$ at a lower concentration with increase in molecular weight. In contrast, when vinyl methyl ether/maleic anhydride copolymers induce mouse peritoneal fluid interferon, ${ }^{3}$ and alt-2-cyclohexyl-1,3dioxepin-5-ene/maleic acid copolymers stimulate the release of superoxide, ${ }^{8}$ high molecular copolymers possess less activity than low molecular ones. As already described, most PSSs suppressed IgM production while PSSs with low $M_{w}$ such as 1800,5400 , and 8000 did not inhibit cell growth at any concentration in this study. Most PSSs suppressed IgM production at lower concentrations than those at which these PSSs inhibited cell growth (see Figures 1 and 2). Thus, PSS may be more effective in suppressing IgM production than inhibiting cell growth, and PSS with appropriate $M_{w}$ may suppress IgM production without inhibiting cell growth. Indeed, IgM production was suppressed to $40 \%$ and $30 \%$ of the control without inhibiting cell growth at $50 \mu \mathrm{g} \mathrm{ml}^{-1}$ of PSS $\left(M_{w}=18000\right)$ and $5 \mu \mathrm{g} \mathrm{ml}^{-1}$ of PSS (35000), respectively. Approximately $1 \mu \mathrm{g} \mathrm{ml}^{-1}$ PSSs $\left(M_{w}=78000\right.$ and 100000$)$ appeared sufficient to suppress IgM production in the same manner, and more PSS with low $M_{w}$ may be required to suppress $\operatorname{IgM}$ production. The results shown in Figures 3 and 4 clearly suggest that PSS suppresses IgM production independently of inhibiting cell growth for a long term. From the results of cell growth in the presence of PSS $\left(M_{w}=78000\right)$ with a broad dispersed molecular weight, the molecular weight distribution of PSS was shown to affect cell growth (see Figure 1). This might be caused by PSS's $\left(M_{w}=78000\right)$ containing high molecular weight components exceeding 100000.

Hybridoma HB4C5 cells independently secret the $\lambda$ light chain with IgM (unpublished data), and thus the results of the SDS-PAGE and western blotting assay of the extracellular IgM showed that PSS decreased $\mu$ heavy chain concentration and had no effect on the independent secretion of $\lambda$ light chain. An antibody is secreted from cells after $\lambda$ light chains and $\mu$ heavy chains are independently synthesized and assembled in cells, and no $\mu$ heavy chain is secreted alone out of cells. ${ }^{19,20}$ The results of ELISA assay of extracellular and intracellular IgM showed that PSS suppresses only the extracellular IgM concentration and has no effect on the intracellular IgM concentration. The results of ELISA assay of the intracellular $\mu$ heavy chain show that there are no differences between $\mu$ heavy chain and IgM concentration in the presence or absence of PSS. Although it was expected that the intracellular concentration of $\mu$ heavy chain and/or IgM would decrease if PSS suppressed the synthesis and/or association of $\lambda$ light and $\mu$ heavy chains after permeating the cells, PSS did not decrease either intracellular concentration. This suggests that PSS suppresses secreting IgM assembled by $\lambda$ light and $\mu$ heavy chains, neither assembling nor synthesizing both chains directly. These results suggest that there is a certain feedback mechanism to keep constant intracellular concentrations of $\mu$ heavy chain and IgM according to the amount of IgM secreted out of cells. Thus it is acceptable that PSS indirectly suppresses the synthesis and association of $\lambda$ light and $\mu$ heavy chains by such a mechanism. Chitosan enhances only extracellular IgM concentration and had no effect on intracellular IgM concentration. As already described, PSS strongly interacts with cell membranes. Therefore, it is probable that extracellular PSS influences cell membranes and suppresses secreting IgM from cells. Support for this speculation is that CBS deleted the suppressive effect of PSS on IgM production, because CBS seemed to adsorb PSS and/or to eliminate PSS adsorbed on cell membranes (see Table III).

PSS had suppressive effect on IgM production of hybridoma cells in a serum-free culture. This shows that new immunosuppressants may develop by modifying PSS. This suggests that 
the production of bioactive materials might be interfered with by an analog of PSS from cation-exchange resins that are mainly crosslinked polystyrenesulfonates widely used for the purification of water and chemicals. Indeed, we have found that partially sulfonated polystyrene suppresses IgM production in the same manner as PSS (data not shown).

\section{REFERENCES}

1. M. M. Yamamoto, Y. Mori, K. Osada, and H. Murakami, Biosci. Biotech. Biochem., in press.

2. M. Maeda, H. Murakami, H. Ohta, and M. Tajima, Biosci. Biotech. Biochem., 56, 427 (1992).

3. T. C. Merigan, Nature, 214, 416 (1967).

4. L. G. Donaruma, R. M. Ottenbrite, and O. Vogel, Ed., "Anionic Polymeric Drugs," John Wiley and Sons, New York, N.Y., 1980.

5. R. M. Ottenbrite and G. B. Butler, Ed., "Anticancer and Interferon Agents," Marcel Decker, Inc., New York, N.Y., 1984.

6. T. Sato, K. Kojima, T. Ihda, J. Sunamoto, and R. M. Ottenbrite, J. Bioactive Compatible Polymers, 1, 448 (1986).

7. Y. Suda, H. Yamamoto, M. Sumi, N. Oku, F. Ito, and R. M. Ottenbrite, J. Bioactive Compatible
Polymers, 7, 15 (1992).

8. Y. Suda, S. Kusumoto, N. Oku, H. Yamamoto, M. Sumi, F. Ito, and R. M. Ottenbrite, J. Bioactive Compatible Polymers, 7, 275 (1992).

9. K. Hatanaka, T. Ohtsuki, and M. Kunou, Chem. Lett., 1407 (1994).

10. T. Matsuda, Y. Nakayama, Y. Tutumi, and T. Mayumi, Polym. Prepr., Jpn., 41, 3301 (1992).

11. K. Park and J. R. Robinson, Int. J. Pharm., 19, 107 (1984).

12. H. Murakami, S. Hashizume, H. Ohashi, K. Shinohara, K. Yasumoto, K. Nomoto, and H. Omura, In Vitro Cell. Develop. Biol., 21, 593 (1985).

13. H. Murakami, H. Masui, G. H. Sato, N. Sueoka, T. P. Chow, and T. Kano-Sueoka, Proc. Natl. Acad. Sci. U.S.A., 79, 1158 (1982).

14. K. Yamada, K. Akiyoshi, H. Murakami, T. Sugahara, I. Ikeda, K. Toyoda, and H. Omura, In Vitro Cell. Develop. Biol., 25, 243 (1989).

15. E. K. Leammli, Nature, 227, 680 (1970).

16. H. Towbin, T. Staehelin, and J. Gordon, Proc. Natl. Acad. Sci. U.S.A., 76, 4350 (1979).

17. H. Tachibana, S. Shirahata, and H. Murakami, Biochem. Biophys. Res. Commun., 189, 625 (1992).

18. R. Richman and R. F. Flinckeringer, Life Sci., 35, 911 (1984).

19. D. G. Bole, L. M. Hendershot, and J. F. Kearney, J. Cell Biol., 102, 1558 (1986).

20. L. M. Hendershot, J. Cell Biol., 111, 829 (1990). 